\title{
PENGEMBANGAN MODEL PENDIDIKAN KARAKTER DI LINGKUNGAN KELUARGA
}

\author{
Ikin Asikin \\ Program Studi Pendidikan Agama Islam, Universitas Islam Bandung \\ Jln. Ranggagading No. 8 Bandung \\ Email: asikini@yahoo.co.id \\ DOI: $10.29313 /$ tjpi.v7i1.3533 \\ Accepted: April 2th, 2018. Approved: July 16th, 2018. Published: July 16th, 2018
}

\begin{abstract}
Education in the family is the foundation of the first and foremost. Parents as first and foremost educators should provide teaching, habituation, modeling, motivation and good enforcement of rules for their children because by providing a process of character education that is good for their children will give effect to the development of the child's character. Meanwhile, by inculcating and internalizing the moral values of Khaliq and makhluq to the children through the process of character education in the form of teaching, habituation, modeling, motivation, and enforcement of the rules in daily life carried out continuously at home, school and community, it will form a child with character noble. So that, in the end, can realize the purpose of human life according to Islam is as Abdullah and Khalifatullah (have a personality all aspects of it realize or reflect the teachings of Islam).
\end{abstract}

Keywords: Model, Character Education, and Family Environment.

\begin{abstract}
ABSTRAK
Pendidikan dalam keluarga merupakan pondasi yang paling pertama dan utama. Orang tua sebagai pendidik yang pertama dan utama hendaklah memberikan pengajaran, pembiasaan, peneladanan, pemotivasian dan penegakekan aturan yang baik bagi anak-anaknya, karena dengan memberikan proses pendidikan karakter yang baik bagi anakanaknya akan memberikan pengaruh terhadap perkembangan karakter anak. Sementara itu dengan menanamkan dan menginternalisasikan nilai-nilai akhlak terhadap khaliq dan makbluq kepada anak melalui proses pendidikan karakter dalam bentuk pengajaran, pembiasaan, peneladanan, pemotivasian dan penegakean aturan dalam kesehariannya dilakukan terus menerus di rumah, sekolab dan masyarakat, maka akan membentuk anak yang berkarakter mulia. Sehingga pada akbirnya dapat mewujudkan tujuan bidup manusia menurut Islam yaitu selaku abdullah dan khalifatullah (mempunyai kepribadian yang seluruh aspek-aspeknya merealisasikan atau mencerminkan ajaran Islam).
\end{abstract}

Kata Kunci: Model, Pendidikan Karakter, dan Lingkungan Keluarga. 


\section{PENDAHULUAN}

Keluarga adalah lingkungan utama yang dapat membentuk watak dan karakter masyarakat. Keluarga adalah lingkungan pertama di mana manusia melakukan komunikasi dan sosialisasi diri dengan manusia lain selain dirinya. Keluarga memiliki tempat dan fungsi yang sangat unik sekaligus dinamis yang memiliki peran sosial, peran pendidikan dan sekaligus peran keagamaan. Keluarga sangat berkontribusi dalam mengontrol jalannya perkembangan anak (Sama'un B, 2005: 98).

Keluarga merupakan masyarakat alamiah yang pergaulan diantara anggotanya bersifat khas. Dalam lingkungan ini terletak dasar-dasar pendidikan. Pendidikan berlangsung dengan sendirinya sesuai dengan tatanan pergaulan yang berlaku di dalamnya, artinya tanpa harus diumumkan atau dituliskan terlebih dahulu agar diketahui dan diikuti oleh seluruh anggota keluarga. Di sini diletakkan dasar-dasar pengalaman melalui rasa kasih sayang dan penuh kecintaan, kebutuhan akan kewibawaan dan nilai-nilai kepatuhan. Justru karena pergaulan yang demikian itu berlangsung dalam hubungan yang bersifat pribadi dan wajar, maka penghayatan terhadapnya mempunyai arti yang amat penting (Zakiyah D, dkk, 2006: 66).

Lembaga pendidikan keluarga menempatkan ibu dan bapak sebagai pendidik kodrati. Hubungan kekeluargaan yang intim dan didasari oleh kasih sayang serta perasaan tulus ikhlas merupakan faktor utama para orang tua dalam membimbing karakter anak-anak (Mahmud, dkk, 2005: 179).

Keluarga adalah lembaga sosial yang pertama dalam masyarakat (WA. Gerungan). $\mathrm{KH}$ Abdullah Gimnastiyar menggeneralisasikan keluarga sebagai sebuah organisasi kecil yang terdiri atas pemimpin (ayah sebagai kepala rumah tangga) dan terpimpin (ibu dan anak). Keluarga terbentuk karena dua hal, yaitu hubungan pernikahan dan hubungan darah. Hubungan pernikahan terbentuk dalam hubungan suami dan istri. Sedangkan hubungan darah terjadi antara ayah, ibu, dan anak-anak. Hubungan ini akan terjadi dalam jangka waktu lama. Setiap keluarga kemudian bersatu membentuk sebuah masyarakat.

Keluarga mempunyai peran vital dalam pembangunan sebuah bangsa. Anak yang berasal dari keluarga yang baik akan terbentuk menjadi manusia yang baik. Anak inilah yang akan menjadi penerus pembangunan bangsa nantinya. Sebaliknya, anak yang berasal dari didikan keluarga yang broken home akan terbentuk menjadi anak yang tidak berkembang. Anak seperti ini tidak mampu melakukan pembangunan terhadap bangsa dan negaranya.

Oleh sebab itu, peran keluarga harus dioptimalkan dalam pembentukan karakter seorang anak. Untuk itu, keluarga harus mampu memerankan 10 fungsinya (Syarbini, 2013) yakni Fungsi reproduksi, Fungsi edukasi, Fungsi proteksi, Fungsi afeksi, Fungsi sosialisasi, Fungsi religi, Fungsi ekonomi, Fungsi biologi, Fungsi transformasi, dan Fungsi rekreasi.

Fungsi edukasi menempatkan keluarga sebagai lembaga pendidikan informal. Keluarga menjadi awal penanaman pengetahuan, sikap dan keterampilan anak. Keluarga mempunyai peran penting terhadap perkembangan pengetahuan anak. Fungsi proteksi maksudnya bahwa keluarga mempunyai kekuatan untuk memberikan rasa aman dan melindungi anggotanya dari berbagai macam gangguan lahir dan bathin. Fungsi afeksi akan memberikan rasa kasih sayang, kebersamaan, dan ikatan bathin kepada seluruh anggotanya. Sebagai lembaga sosialiasi, keluarga mempunyai fungsi untuk melatih anak bersosialisasi atau bergaul dengan orang lain.

Fungsi keluarga yang sangat penting adalah fungsi religi. Keluarga mempunyai tanggung jawab mengenalkan konsep ketuhanan dan pelaksanaan ibadah keagamaan kepada anggota keluarga. Keluarga wajib menanamkan semangat ketuhanan yang benar kepada anak-anak. 
Fungsi ekonomi, fungsi biologi, dan fungsi rekreasi merupakan fungsi keluarga dalam rangka memenuhi segala kebutuhan hidup manusia, baik kebutuhan jasmani dan kebutuhan rohani. Sedangkan fungsi transformasi adalah fungsi keluarga dalam mentransfer nilai-nilai keluarga kepada anak cucunya.

Seluruh fungsi keluarga secara bersinergi membantu penanaman nilai pendidikan karakter bagi anak-anak. Sebagaimana dijelaskan pada bab sebelumnya, pendidikan karakter di lingkungan keluarga juga mencakup aspekaspek afektif, kognitif, dan psikomotor. Menurut Syarbini (2014: 40), nilai-nilai karakter yang dapat ditanamkan dalam pendidikan karakter di keluarga meliputi keimanan dan ketaqwaan, kejujuran, disiplin, percaya diri, tanggung jawab, rasa keadilan, sopan santun, pemaaf, sabar, dan peduli. Nilai-nilai karakter ini dikembangkan dari ajaran agama, filsafat bangsa, serta nilai kearifan lokal suatu masyarakat.

Sejalan dengan tujuan pendidikan secara umum, pendidikan karakter pada hakekatnya bertujuan menciptakan manusia yang cerdas pikiran, moral dan spiritualnya, berbudi pekerti yang luhur, taat menjalankan perintah agama, serta mempunyai mental yang terpuji. Namun secara khusus, penanaman pendidikan karakter di lingkungan keluarga bertujuan untuk menciptakan anak menjadi manusia yang berakhlak mulia, taat kepada perintah agamanya (baca: Allah dan Rasul) serta menjadi anak yang berbakti kepada kedua orang tua.

Untuk mencapai tujuan di atas, penanaman pendidikan karakter di keluarga dapat dilakukan oleh dua pelaku. Pelaku pertama adalah keluarga inti (orang tua dan kakak adik). Ada dua alasan, yaitu orang tua telah dikodratkan untuk mendidik anak-anak yang dilahirkannya serta aspek kepentingan orang tua terhadap kesuksesan anakanaknya. (Tafsir, 2004: 74). Orang tua sangat bertanggung jawab menjadikan anakanaknya menjadi insan yang berguna.
Pelaku kedua, keluarga besar. Maksud keluarga besar disini adalah kakek, nenek, paman, bibi, saudara-saudara lainnya. Unsur-unsur ini bisa berpengaruh terhadap keberhasilan penanaman karakter di lingkungan keluarga. Ketika orang tua mengajarkan untuk sholat, tetapi di sisi lain anak-anak melihat kakek atau paman atau bibi tidak shalat, maka kepekaan anak untuk menuruti perintah orang tua akan sedikit goyah. Mereka bisa berdalih mengapa mereka saja yang shalat sedangkan orang lain tidak mengerjakannya. Oleh karena itu, perlu ada kesamaan pikiran, visi dan misi antara kedua perilaku di atas agar penanaman karakter di lingkungan keluarga berjalan secara utuh.

Selain contoh mengajarkan ibadah, pendidikan karakter di lingkungan keluarga juga mengutamakan pendidikan akhlak mulia. Dalam peran menjadi seorang guru, Orang tua harus mampu memberikan contoh atau teladan yang baik kepada anakanaknya. Karena sebagai seorang peserta didik, anak-anak mengikuti penuh apa yang dilakukan dan dikatakan oleh gurunya (orang tuanya).

Ibarat kurikulum dalam pendidikan formal, Orang tua harus mengajarkan materi-materi tentang sopan santun, cara berbicara yang sopan, berjalan yang benar, berkomunikasi yang sopan, bertanggung jawab, bersikap jujur, suka membantu orang lain, serta pengajaran-pengajaran lainnya. Jika dikaitkan dengan pengetahuan majemuk-nya Howard Gardner, pendidikan karakter di keluarga cenderung bertujuan meningkatkan kecerdasan interpersonal dan kecerdasan intrapersonal. Masalah ini dapat dirumuskan ke dalam beberapa pertanyaan berikut: (1). Bagaimana peranan keluarga dalam pendidikan karakter ? (2). Karakter apa yang dikembangkan dalam pendidikan karakter di lingkungan keluarga? dan (3). Bagaimana pendekatan yang dilakukan dalam pendidikan karakter di lingkungan keluarga? 


\section{PEMBAHASAN}

\section{Peran Orang Tua dalam Pendidikan Karakter}

Keluarga adalah lingkungan pertama dan utama yang dapat membentuk watak dan karakter masyarakat. Keluarga memiliki tempat dan fungsi yang sangat unik sekaligus dinamis. Keluarga memiliki peran sosial, peran pendidikan dan sekaligus peran keagamaan. Keluarga sangat berkontribusi dalam mengontrol jalannya perkembangan anak (Sama'un B, 2005: 98).

Lembaga pendidikan keluarga menempatkan ibu dan bapak sebagai pendidik kodrati. Hubungan kekeluargaan yang intim dan didasari oleh kasih sayang serta perasaan tulus ikhlas merupakan faktor utama para orang tua dalam membimbing anak-anak (Mahmud, dkk, 2005: 179).

Pada umumnya, pendidikan dalam keluarga itu bukan berpangkal tolak dari kesadaran dan pengertian yang lahir dari pengetahuan mendidik, melainkan karena secara kodrati suasana dan strukturnya memberikan kemungkinan alami membangun situasi pendidikan. Situasi pendidikan itu terwujud berkat adanya pergaulan dan hubungan pengaruh mempengaruhi secara timbal balik antara orang tua dan anak (Zakiah D, dkk, 2006: 35). Untuk itu sudah sepantasnya orang tua menjadi teladan yang baik bagi anak.

Secara khusus dalam Islam, disebutkan bahwa pelaksanaan pendidikan anak merupakan amanat besar dari Allah. Karenanya, keteledoran dan penyelewengan pendidikan anak dari manhaj yang telah ditentukan merupakan pengkhianatan terhadap amanat besar itu. Mengingat besarnya tanggung jawab para pelaksana pendidikan, Allah Yang Maha Suci akan memberikan imbalan yang pantas bagi mereka (Jaudah MA, 1995: 83).

Mengenai pentingnya peranan orang tua dalam membina karakter anak dinyatakan Al-Quran dan hadis secara jelas, diantaranya:
Pertama. Dalam Surat At-Tahrim ayat 6, Allah SWT berfirman:

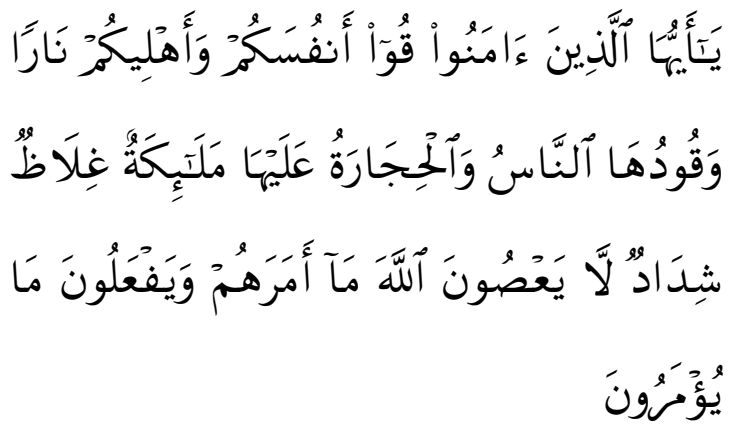

Hai orang-orang yang beriman, peliharalab dirimu dan keluargamu dari api neraka yang bahan bakarnya adalah manusia dan batu; penjaganya malaikat-malaikat yang kasar, keras, dan tidak mendurhakai Allah terbadap apa yang diperintabkanNya kepada mereka dan selalu mengerjakan apa yang diperintabkan (Depag, 2006: 560).

Kedua. Betapa pentingnya pendidikan agama dalam lingkungan keluarga, karena bagi seorang anak ketika ia dilahirkan ke dunia dalam keadaan tidak berdaya, maka orang tua (Ibu dan Bapak) yang harus mengembangkan anak yang lahir di dalamnya. Proses pengembangan anak dimaksud adalah pembentukan anak baik secara fisik maupun psikis, watak maupun kepribadiannya (Sama'un B, 2005: 104)

Hal ini sebagaimana sabda Nabi Muhammad saw. sebagai berikut:
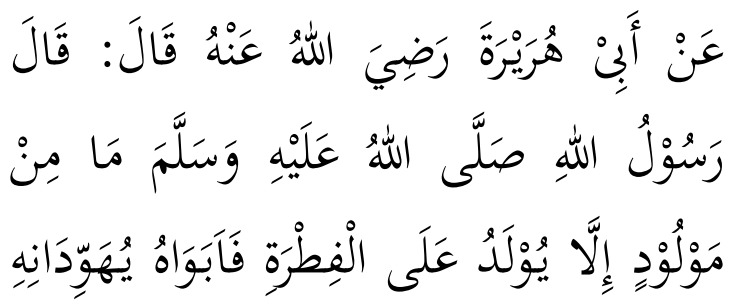

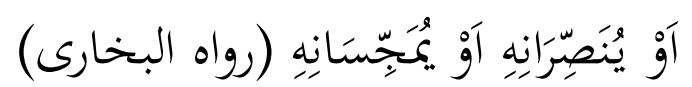

Diriwayatkan dari Abu Hurairah r.a. Rasulullah saw. pernab bersabda, Setiap anak dilabirkan berada dalam keadaan fitrah (keimanan terhadap taubid tetapi kedua orang tuanyalah yang menjadikan dia seorang Yabudi, Nasrani atau 
Majusi. (HR Bukhari dan Muslim) (Az-Zabidi, 2002: 114).

Berdasarkan dalil-dalil tersebut dapat diketahui bahwa secara moral kedua orang tua mempunyai tanggung jawab untuk memelihara, mengawasi dan melindungi serta membimbing keturunan mereka. Sebab, menurut ajaran Islam anak adalah amanat Allah SWT, amanat wajib dipertanggungjawabkan dan tanggung jawab itu diantaranya adalah menyelenggarakan pendidikan bagi anak-anak dalam keluarga (Sama'un B, 2005: 114).

\section{Bentuk-bentuk Pendidikan Karakter dalam Keluarga}

Zakiah Daradjat menyatakan bahwa, "Pada umumnya agama seseorang ditentukan oleh pendidikan, pengalaman dan latihan-latihan yang dilaluinya pada masa kecil dulu. Seseorang yang pada masa kecilnya tidak pernah mendapatkan pendidikan agama, maka pada dewasanya nanti ia tidak akan merasakan pentingnya agama dalam hidupnya" (Zakiah D, 1991: 35).

Berdasarkan pendapat tersebut dapat diketahui bahwa pendidikan karakter merupakan pondasi penting dalam penanaman karakter terhadap anak. Dalam menanamkan karakter terhadap anak terdapat tahapan-tahapan tertentu. Tahapantahapan pendidikan anak dalam ajaran Islam menurut Ramayulis dalam bukunya "Imu Pendidikan Islam" sebagai berikut:

Pertama, Tahap pra nikah. Mendidik anak dimulai saat seorang lakilaki ingin mencari calon pendamping hidupnya. Hal ini disebabkan karena pendidikan anak nantinya akan sangat tergantung kepada kualitas pasangan hidupnya.

Kedua, Tahap Pernikahan. Setelah calon dipilih, diadakan peminang, selanjutnya di laksanakan pernikahan dengan walimat al-'urusy-nya. Sesuatu yang menarik dalam pernikahan dalam Islam adalah dibacakannya khutbah nikah sebelum ijab qabul. Dalam khutbah nikah terkandung nilai-nilai pendidikan, yaitu: (a) peningkatan iman dan amal, (b) pergaulan baik antara suami dengan istri, (c) kerukunan rumah tangga, (d) memelihara silaturahmi, (e) mawas diri dalam segala tindak dan perilaku. Setelah pernikahan selesai, maka suami istri sudah boleh bergaul dengan melakukan persetubuh disunatkan membaca doa sebagai berikut:

"Dengan nama Allah, ya Allah jaubkan syetan dari kami dan jaubkan syetan itu dari anak yang (mungkin) Engkau karuniakan kepada kami. "(H.R.Muttafaq'alaih.)

Ketiga, Tahap pranatal. Islam juga menganjurkan untuk melakukan pendidikkan ketika anak masih dalam kandungan. Seperti: (a) seorang ibu yang telah hamil harus mendo'akan anaknya; (b) harus selalu menjaga dirinya agar tetap memakan makanan dan minum-minuman yang halal; (c) taqarrub (mendekatkan diri) kepada Allah SWT selalu mendekatkan diri kepada Allah melalui ibadah wajib maupun ibadah sunnat; (d) Kedua orang tua berakhlak mulia

Keempat, Tahap natal. Pendidikan setelah anak lahir dapat dimulai dengan: (a) Memberikan ucapan selamat. Hal ini bertujuan ntuk menanamkan rasa solidaritas antar sesama muslim kepada anak; (b) Memperdengarkan kalimat-kalimat thayyibah berupa adzan dan iqamat. Hal ini dimaksudkan agar suara yang pertama kali terdengar oleh anak adalah kalimat-kalimat yang baik. Sehingga setan akan takut untuk mendekati dan mengganggunya; (c) Menggosok langit-langit mulut anak setelah dilahirkan. Maksudnya adalah mengunyahkan kurma dan menggosokkannya dilangit-langit mulut anak. Hal ini bertujuan untuk menguatkan syaraf-syaraf mulut dan tenggorokan anak; dan (d) Melakukan aqiqah pada hari ketujuh dari kelahirannya. Hal ini juga bisa dilakukan pada hari ke-14 dan 21 bagi yang tidak mampu. Pada saat aqiqab ini yang perlu dilakukan adalah: memotong rambut anak, 
bersedekah dan memberikan nama yang baik untuk anak.

Kelima, Tahap anak-anak dan remaja.

Mengenalkan hukum-hukum halal dan haram kepada anak sejak sedini mungkin. Membiasakan kepada anak untuk selalu menjalankan ibadah. Membiasakan anak untuk selalu membaca Al-Qur'an. Menjauhkan anak dari sifat-sifat berikut: berbohong, mencuri, mencela dan mencemooh, kenakalan dan penyimpangan lainnya (Ramayulis, 2002: 302-313).

Model pendidikan karakter yang dapat diterapkan dalam lingkungan keluarga yaitu melalui:

Pengajaran. Pendidikan karakter dimulai dengan memberikan pengajaran nilai-nilai Islami kepada anak didik. Memberikan pengajaran kepada anak didik nilai-nilai baik yang harus dimiliki dan nilainilai buruk yang harus dihindari. Perilaku mana yang baik harus dilakukan dan perilaku mana yang buruk yang harus dijauhi. Intinya, memberikan pengajaran kepada anak didik untuk memahami dan mempraktikkan nilainilai karakter yang baik/ terpuji, serta menghindari sifat-sifat dan nilai karakter yang buruk/ tercela.

Pembiasaan. Dalam pendidikan karakter, pembiasaan memiliki posisi sangat penting sebagai bagian dari proses pembentukan sikap dan perilaku yang relatif menetap dan bersifat otomatis melalui proses pembelajaran yang berulang-ulang. Sikap atau perilaku yang telah menjadi kebiasaan mempunyai ciri: 1) perilaku tersebut relatif menetap; 2) pembiasaan umumnya tidak memerlukan fungsi berpikir tinggi; 3) kebiasaan bukan sebagai hasil dari proses kematangan, tetapi sebagai akibat atau hasil pengalaman atau belajar; 4) kebiasaan tampil berulang-ulang sebagai respon terhadap stimulus yang sama.

Peneladanan. Pendidikan karakter dengan memberikan uswah hasanah, contoh teladan yang baik. Anak belajar dari lingkungannya dan dari orang-orang dewasa yang berada di sekitarnya. Sikap imitasi atau meniru sangat menonjol pada usia anak.
Perkembangan aspek-aspek psikologis dan kemampuan anak yang lain yang berkembang lewat proses peniruan, pada mulanya anak beragama karena meniru orang tuanya. Salah satu ciri kehidupan beragama pada masa kanak-kanak adalah sifatnya yang imitatif. Artinya anak-anak hanya menirukan apa yang diyakini dan dilakukan orang tuanya.

Pemotivasian. Beberapa bentuk dan cara motivasi antara lain: memberi penghargaan berupa angka, hadiah, kompetisi, mengetahui hasil, pujian, hukuman, hasrat untuk belajar, minat, tujuan yang diakui. Memotivasi berarti juga melibatkan anak didik dalam proses pendidikan. Mereka diberi kesempatan untuk berkembang secara optimal dan mengeksplorasi seluruh potensi yang dianugerahkan Allah kepadanya..

Penegakkan aturan. Penegakkan aturan merupakan aspek yang harus diperhatikan terutama pendidikan karakter. Pada proses awal pendidikan karakter, penegakkan aturan merupakan setting limit dimana ada batasan yang jelas dan tegas mana yang harus dan tidak harus dilakukan, mana yang boleh dan tidak boleh dilakukan oleh anak (Aan H, 2012: 134-138).

Hal senada diungkapkan oleh Abdullah Ulwan mengenai model dalam pembentukan karakter anak dalam keluarga yaitu 1) Pendidikan dengan keteladanan; 2) Pendidikan dengan adat kebiasaan; 3) pendidikan dengan nasihat; 4) pendidikan dengan perhatian/ pengawasan; 5) pendidikan dengan hukuman (Abdullah Ulwan, 1978: 141-142).

Penulis akan uraikan penerapan pendidikan karakter dalam keluarga menurut beberapa pendapat yang pada intinya mengarah kepada lima model pendidikan karakter dalam keluarga.

Menurut Abdullah Ulwan bahwa penerapan pendidikan karakter yang baik yaitu dengan selalu memperhatikan terhadap gerak-gerik, ucapan, perbuatan dan orientasinya. Jika melihat sesuatu yang baik, dihormati, doronglah anak untuk 
melakukannya. Jika melihat sesuatu yang jahat, cegahlah mereka, berilah peringatan dan jelaskanlah akibat yang membinasakan dan membahayakan. Jika orang tua melalaikan anaknya, sudah barang tentu anak akan menyeleweng dan terjerumus ke jurang kehancuran dan kebinasaan (Abdullah Ulwan, 1978: 729).

Selain itu, para orangtua hendaknya memperhatikan sifat kejujuran anak, sifat amanah anak, sifat menjaga lisan anak, dan gejala kejiwaan dan kehendak anak. Oleh sebab itu hendaklah orangtua mengikuti semua cara dalam upaya memperbaiki dan menyelamatkan moral anak dari hal-hal yang negatif, sehingga anaknya kembali dalam barisan orang-orang yang bertakwa dan orang-orang saleh pilihan. Karenanya, memberikan perhatian dan memperhatikan adalah masalah terpenting dalam mengungkapkan hakikat yang terselubung dalam diri anak, dan menyingkap tabir yang menutup perbuatan anak berupa kejahatan. Bahkan hendaknya orangtua memberikan gambaran realitas yang sempurna tentang moralitas anak, dan kelakuannya dalam kehidupan (Abdullah Ulwan, 1978: 740).

Menurut Syamsu Yusuf LN, ada beberapa hal yang perlu menjadi kepedulian (perhatian) orangtua dalam mengembangkan akhlak mulia/ karakter yang baik bagi anak dalam lingkungan keluarga, yaitu: (a) Karena orangtua merupakan pembina pribadi yang pertama bagi anak, dan tokoh yang diidentifikasi atau ditiru anak, maka seyogianya ia memiliki kepribadian yang baik atau ber-akblakul karimah (akhlak yang mulia); (b) Kepribadian orangtua, baik yang menyangkut sikap, kebiasaan berperilaku atau tatacara hidupnya merupakan unsurunsur pendidikan yang tidak langsung memberikan pengaruh terhadap perkembangan fitrah beragama anak; (c) Orangtua hendaknya memperlakukan anaknya dengan baik. Sikap dan perlakuan orangtua yang baik adalah yang mempunyai karakteristik: 1) memberikan curahan kasih sayang yang ikhlas; 2) bersikap respek/ menghargai pribadi anak; 3) menerima anak sebagaimana biasanya; 4) mau mendengar pendapat/ keluhan anak; 5) memaafkan kesalahan anak dan meminta maaf bila ternyata orangtua sendiri salah kepada anak; dan 6) meluruskan kesalahan anak dengan pertimbangan atau alasan-alasan yang tepat; (d) Orangtua hendaknya memelihara hubungan yang harmonis antaranggota keluarga (ayah dengan ibu, orangtua dengan anak, dan anak dengan anak). Hubungan yang harmonis, penuh pengertian dan kasih sayang akan membuahkan perkembangan perilaku anak yang baik, namun bila sebaliknya akan membuahkan perkembangan perilaku anak yang tidak baik; dan (e) Orangtua hendaknya membimbing, mengajarkan, atau melatihkan ajaran agama terhadap anak, seperti: syahadat, salat (bacaan dan gerakannya), berwudu, doa-doa, bacaan Al-Quran, lafaz zikir dan akhlak terpuji (akblakul mahmudah) (Syamsu Yusuf, 2012: 138-139).

Menurut Abdurrahman an-Nahlawi bahwa kewajiban orangtua dalam penanaman karakter yang mulia terhadap anak yaitu: (a) Membiasakan anak supaya mengingat keagungan dan nikmat Allah swt., mencari dalil atas keesaan-Nya dari dampak kekuasaan-Nya guna merealisasikan kesucian fitrah anak serta kesiapannya untuk mentauhidkan dan mengagungkan Allah SW'T; (b) Menampakkan keteguhan sikap dihadapan anak dalam menghadapi berbagai penyimpangan orang sesat, orang yang dimurkai, orang-orang musyrik dan para pengikutnya. Penyimpangan seperti kedhaliman, hidup tak bermoral, kemewahan dan kerusakan yang timbul akibat dari filmfilm, surat-surat kabar yang menyimpang, cerita-cerita dan majalah-majalah yang membujukkan kesesatan (Abdurrahman A, 1996: 202).

Untuk melengkapi uraian dalam kajian ini perlu dicermati nasihat-nasihat AlGhazali dalam rangka pendidikan karakter anak. Al-Ghazali memberi nasihat dengan empat hal, yaitu:

(a) Hendaknya anak-anak dibiasakan dengan karakter yang terpuji dan perbuatan 
yang baik serta dijauhkan dari perbuatan yang buruk dan rendah. Hendaklah ditanamkan dalam diri anak-anak tersebut sifat-sifat pemberani, sabar, dan rendah hati, menghormati teman dan orang yang lebih tua, sedikit bicara, suka mendengarkan halhal yang baik, taat kepada kedua orang tua dan kepada guru serta pendidikannya. Di samping itu, hendaklah diajarkan pada anakanak agar menjauhi perkataan yang tak berguna dan kotor, congkak terhadap temanteman mereka, atau melakukan suatu perbuatan yang tidak pernah dilakukan oleh kedua orang tua. Menurut al-Ghazali, mendidik karakter anak merupakan pekerjaan yang bernilai tinggi dan paling penting, karena anak menurutnya adalah amanah Allah bagi orang tuanya yang hatinya bersih dan suci bagaikan mutiara yang cemerlang dan jiwanya sederhana yang kosong dari segala lukisan atau ukiran. Anakanak itu akan menerima segala sesuatu yang diukirkan padanya serta condong kepada sesuatu yang mengotorinya. Jika anak dibiasakan dengan kebiasaan yang baik, ia akan tumbuh menjadi baik dan ia akan bahagia di dunia dan di akhirat, sedang orang tuanya ikut mendapat pahala, juga guru dan para pendidiknya mendapatkan pahala. Jika ia dibiasakan dengan perbuatan buruk, maka ia akan celaka dan rusak dan orang tuanya akan mendapatkan beban dosa.

(b) Hendaknya karakter baik dan perbuatan yang baik anak didorong untuk berkembang dan ia selalu dimotivasi untuk berani berbuat baik dan berkarakter mulia. Dalam hubungan ini al-Ghazali menegaskan, bila dalam diri anak itu nampak jelas karakter dan perbuatan terpuji, maka hendaklah ia dipuji dan diberi hadiah (rewards) yang menyenangkannya serta disanjung di hadapan orang banyak.

(c) Hendaknya jangan mencela anak dan hendaknya membuat jera berbuat kesalahan (dosa). Al-Ghazali menegaskan, jangan banyak berbicara terhadap anak dengan umpatan dan celaan pada sekali waktu, karena itu akan menyebabkan ia meremehkan bila mendengar celaan dan menganggap remeh perbuatan buruk yang dilakukannya serta menyebabkan hatinya kebal terhadap ucapan atau meremehkannya, akan tetapi hendaknya orang tua menjaga wibawanya dalam berbicara dengannya dan janganlah sekali-kali mengahardiknya. Ibunya hendaknya jangan menakut-nakuti dengan kemarahan ayahnya, tetapi menjauhkan dari keburukan perbuatannya. Jadi, Al-Ghazali menghendaki agar anak dijauhkan dari pengaruh kegoncangan emosional akibat terlalu banyak dicela dan semakin banyak celaan diberikan terhadap anak, tidak akan membawa perbaikan terhadap perilaku anak, tetapi justeru membuat perasaannya menjadi mati.

(d) Kepada anak-anak yang sudah dewasa (baligh) hendaknya diajarkan hukumhukum syariah dan masalah-masalah keagamaan. Jangan sekali-kali orang tua atau pendidik mentolelir anak meninggalkan shalat dan bersuci. Jika anak semakin dewasa, maka ia harus diberikan pendidikan tentang rahasia syariah atau hikmah dari ajaran-ajaran agama yang diberikan kepadanya (Ali AlJumbulati, dkk, 1994: 152-154).

Berdasarkan paparan di atas maka orangtua dituntut untuk menjadi pendidik yang memberikan pengetahuan pada anakanaknya, serta memberikan sikap dan keterampilan yang memadai, memimpin keluarga, dan mengatur kehidupannya, memberikan contoh sebagai keluarga yang ideal, dan bertanggung jawab dalam kehidupan keluarga, baik yang bersifat jasmani maupun rohani (Muhaimin, dkk, 1993: 292).

\section{Karakter yang Dikembangkan dalam Pendidikan Karakter di Lingkungan Keluarga}

Secara umum akhlak dibagi menjadi dua, yaitu akhlak mulia (al-akblaq almahmudab) dan akhlak tercela (al-akblaq almadrmumah). Jika dilihat dari ruang lingkupnya, akhlak dibagi menjadi dua bagian, yaitu akhlak terhadap Khaliq (Allah Swt.) dan akhlak terhadap makbluq 
(makhluk/selain Allah Swt.). Akhlak terhadap makhluk bisa dirinci lagi menjadi beberapa macam, seperti akhlak terhadap sesama manusia, akhlak terhadap makhluk hidup selain manusia (seperti tumbuhan dan binatang), serta akhlak terhadap benda mati (lingkungan alam).

Berkaitan dengan hal tersebut, maka tulisan ini akan membicarakan tentang akhlak yang perlu dikembangkan dalam pendidikan keluarga yaitu akhlak terhadap kbaliq (Allah SWT) dan akhlak terhadap makbluq.

\section{Akhlak terhadap Khaliq}

Titik tolak akhlak terhadap khaliq adalah pengakuan dan kesadaran bahwa tiada tuhan melainkan Allah. Kepada Allah SWT, manusia harus menerapkan akhlak yang baik, mulia dan luhur. Paling tidak ada empat alasan mengenai hal ini. Pertama; Allahlah yang telah menciptakan manusia (lihat QS Al-Thariq: 5-7 dan Al-Mu'minun: 12-13). Kedua; Allahlah yang telah memberikan perlengkapan panca indra, akal pikiran, hati sanubari, di samping anggota badan yang kokoh dan sempurna (lihat QS An-Nahl: 78). Ketiga, Allahlah yang telah menyediakan berbagai bahan dan sarana yang diperlukan bagi kelangsungan hidup manusia (lihat QS Al-Jatsiyah: 12-13). Dan keempat, Allahlah yang telah memuliakan manusia dengan cara memberi kemampuan menguasai daratan dan lautan (lihat QS Al-Isra': 70) (M. Quraish S, 2000: 262).

Adapun contoh akhlak terhadap Allah antara lain yang pertama, mencintai Allah melebihi cinta kepada apa dan siapapun juga dengan mempergunakan firman-Nya dalam Al-Quran sebagai pedoman hidup dan kehidupan; kedua, melaksanakan segala perintah dan menjauhi segala larangan-Nya; ketiga, mengharapkan dan berusaha memperoleh keridaan Allah; keempat, mensyukuri nikmat dan karunia Allah; kelima, menerima dengan ikhlas semua kada dan kadar ilahi setelah berikhtiar maksimal; keenam, memohon ampun hanya kepada Allah; ketujuh, bertaubat hanya kepada Allah, dan kedelapan berserah diri kepada Allah (M. Daud A, 1998: 356-357).

\section{Akhlak terhadap Sesama Manusia}

Banyak sekali rincian yang dikemukakan Al-Quran berkaitan dengan perlakuan terhadap sesama manusia. Petunjuk mengenai ini bukan hanya dalam bentuk larangan melakukan hal-hal negatif seperti membunuh, menyakiti badan, atau mengambil harta tanpa alasan yang benar, melainkan juga sampai kepada menyakiti hati dengan jalan menceritakan aib seseorang di belakangnya, tidak peduli aib itu benar atau salah walaupun sambil memberikan materi kepada yang disakiti hatinya itu. (Lihat QS Al-Baqarah: 263) (M. Quraish S, 2000: 266267).

Akhlak terhadap manusia dapat dirinci sebagai berikut: (a) Akhlak terhadap rasulullah, antara lain mencintai Rasulullah secara tulus mengikuti semua sunnahnya, menjadikan rasulullah sebagai idola, menjalankan apa yang disuruhnya dan tidak melakukan apa yang dilarangnya. (b) Akhlak terhadap orangtua, antara lain mencintai mereka melebihi mencintai kepada kerabat lainnya, merendahkan diri kepadanya diiringi perasaan kasih sayang, berkomunikasi dengan kata-kata lemah lembut, dan mendoakan mereka. (c) Akhlak terhadap diri sendiri, antara lain memelihara kesucian diri, menutup aurat, jujur, ikhlas, sabar, rendah hati, menjauhi dengki, menjauhi dendam, belaku adil, menjauhi segala perkataan dan perbuatan sia-sia.

(d) Akhlak terhadap keluarga, antara lain saling membina rasa cinta dan kasih sayang dalam kehidupan keluarga, saling menunaikan kewajiban untuk memperoleh hak, berbakti kepada ibu dan bapak, mendidik anak dengan kasih sayang, dan memelihara silaturahmi yang dibina orangtua yang telah meninggal dunia. (e) Akhlak terhadap tetangga, antara lain saling mengunjungi, saling membantu, saling memberi, saling menghormati, saling 
menghindari pertengkaran dan permusuhan. (f) Akhlak terhadap masyarakat, antara lain memuliakan tamu, menghormati nilai dan norma yang berlaku dalam masyarakat, saling tolong menolong dalam kebajikan dan takwa, menganjurkan anggota masyarakat termasuk diri sendiri berbuat baik dan mencegah melakukan perbuatan jahat, memberi makan fakir miskin, menunaikan amanah, dan menepati janji (M. Daud A, 1998: 357-358).

\section{Akhlak terhadap Lingkungan}

Lingkungan adalah segala sesuatu yang ada di sekitar manusia, baik binatang, tumbuh-tumbuhan maupun benda-benda lain yang tidak bernyawa. Akhlak terhadap lingkungan ini diajarkan oleh Al-Quran berdasarkan fungsi manusia sebagai khilafah di muka bumi. Sebagai khilafah di muka bumi, manusia harus mengayomi dan memelihara lingkungan (lihat QS Al-An'am: 38 dan Al-Hasyr: 5) (M. Quraish S, 2000: 261-271). Berkaitan dengan hal ini Rasulullah saw. bersabda:
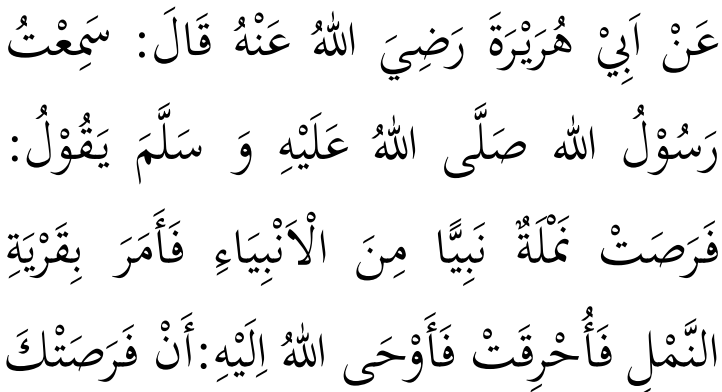

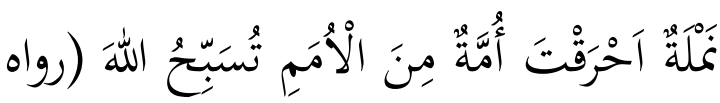

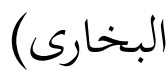

Diriwayatkan dari Abu Hurairah r.a.: Aku pernah mendengar Rasulullah saw. bersabda, seekor semut menggigit seorang nabi di antara nabi-nabi, dan ia menyurub membakar sarang semut itu. Maka Allah menegurnya, apakah karena seekor semut yang menggigitmu, kamu mesti membakar sebuah bangsa yang mengagungkanku? (H.R. Bukhari) (Az-Zabidi, 2002: 531-532).
Dengan menanamkan dan menginternalisasikan nilai-nilai akhlak terhadap khaliq dan makhluq kepada anak melalui proses pendidikan karakter dalam bentuk pengajaran, pembiasaan, peneladanan, pemotivasian dan penegakkan aturan dalam kesehariannya. Proses pembentukan karakter ini dilakukan terus menerus di rumah, sekolah dan masyarakat, maka akan membentuk anak yang berkarakter mulia (Aan H, 2012: 190). Sehingga pada akhirnya dapat mewujudkan tujuan hidup manusia menurut Islam yaitu selaku abdullah dan khalifatullah (mempunyai kepribadian yang seluruh aspek-aspeknya merealisasikan atau mencerminkan ajaran Islam) (Ahmad, D M, 1986: 45-47).

\section{KESMIPULAN}

Pendidikan dalam keluarga merupakan pondasi yang paling pertama dan utama terhadap perkembangan anak karena secara mental-spiritual, dasar-dasar pendidikan diletakkan oleh keluarga. Orang tua sebagai pendidik yang pertama dan utama hendaklah memberikan pengajaran, pembiasaan, peneladanan, pemotivasian dan penegakkan aturan yang baik bagi anakanaknya, karena dengan memberikan proses pendidikan karakter yang baik bagi anakanaknya akan memberikan pengaruh terhadap perkembangan karakter anak.

Sementara itu dengan menanamkan dan menginternalisasikan nilai-nilai akhlak terhadap khaliq dan makhluq kepada anak melalui proses pendidikan karakter dalam bentuk pengajaran, pembiasaan, peneladanan, pemotivasian dan penegakkan aturan dalam kesehariannya dilakukan terus menerus di rumah, sekolah dan masyarakat, maka akan membentuk anak yang berkarakter mulia. Sehingga pada akhirnya dapat mewujudkan tujuan hidup manusia menurut Islam yaitu selaku abdullah dan khalifatullah (mempunyai kepribadian yang seluruh aspek-aspeknya merealisasikan atau mencerminkan ajaran Islam). 


\section{DAFTAR PUSTAKA}

Al-Jumbulati, Ali dan Abdul Fatah AtTuwaanisi. (1994). Perbandingan Pendidikan Islam, terj. H.M. Arifin. Jakarta: Rineka Cipta.

Ali, Mohammad Daud. (1998). Pendidikan Agama Islam. Jakarta: PT RajaGrafindo Persada.

An-Nahlawi, Abdurrahman. (1996). Prinsipprinsip dan Metoda Pendidikan Islam. Bandung: cv. Diponegoro.

Awwad, Jaudah Muhammad. (1995). Mendidik Anak Secara Islam. Jakarta: Gema Insani.

Az-Zabidi. (2002). Ringkasan Shabih AlBukhari. Cet. VI. Bandung: Mizan Media Utama.

Bakry, Sama’un. (2005). Menggagas Konsep Ilmu Pendidikan Islam. Bandung: Pustaka Bani Quraisy.

Darajat, Zakiah. (1991). Ilmu Jiwa Agama. Cet. ke-13. Jakarta: PT Bulan Bintang. dkk. (2006). Ilmu Pendidikan Islam. Jakarta: Bumi Aksara.

Departemen Agama RI. (2006). Al-Quran Tajwid dan Terjemahnya. Bandung: Syaamil Al-Quran.

Hasanah, Aan. (2012). Pendidikan Karakter Berperspektif Islam. Bandung: Insan Komunika.

LN, Syamsu Yusuf. (2012). Psikologi Perkembangan Anak dan Remaja. Cet. ke-13 Bandung: Remaja Rosdakarya.

Mahmud, dan Tedi Priatna. (2005). Pemikiran Pendidikan Islam. Bandung: Sahifa.

Marimba, Ahmad D. (1986). Pengantar Filsafat Pendidikan Islam. Bandung: Al-Ma'arif.

Muhaimin, dan Abdul Mujib. (1993). Pemikiran Pendidikan Islam. Bandung: Trigenda Karya.

Ramayulis. (2002). Ilmu Pendidikan Islam. Jakarta: Kalam Mulia.

Shihab, M. Quraish. (2000). Wawasan AlQuran: Tafsir Maudhu'i atas Pelbagai Persoalan Umat. Bandung: Mizan.
Ulwan, Abdullah. (1978). Tarbiyatul Aulad fil Islam Juг. II. Cet. II. Beirut: Darussalam. 